\title{
Hubungan Faktor Persepsi Mahasiswa Dalam Pengelolaan Ruang Rawat Inap Terhadap Kepuasan Mahasiswa Dalam Praktek Klinik Keperawatan Di RSUD Pariaman
}

\author{
Mechi Silvia Dora ${ }^{a}$, Dini Qurata Ayuni ${ }^{\text {b }}$
}

\author{
${ }^{1}$ STIKes Piala Sakti Pariaman, Sei.Rambai, Pariaman, Sumatera Barat ,Indonesia \\ ${ }^{2}$, STIKes Piala Sakti Pariaman, Marunggi, Pariaman, Sumatera Barat ,Indonesia \\ e-mail : mechidora.88@gmail.com
}

\begin{abstract}
The success of students in clinical nursing practice is largely determined how the inpatient room management is perceived by students as a form of experience required. The purpose of this study was to analyze the effect of student perception factors in the management of inpatient rooms on student satisfaction in nursing clinical practice. This type of research is observational with quantitative analysis methods. The design of this study is a cross sectional study. The results of the bivariate analysis showed that there was a correlation between students' perceptions about clinical leadership. leadership (p-value 0.003), supervision of the head of the room ( $p$-value 0.042 ), coordination between practice supervisors ( $p$-value 0.032), and practical work environment ( $p$-value 0.033 ) with student satisfaction in nursing clinical practice. The results of multivariate analysis showed that the most influential effect on student satisfaction in nursing clinical practice was about clinical leadership leadership (p-value $0.012<0.05$ and $\operatorname{Exp}(B) 3.436$ ) and work environment (p-value $0.010<0.05$ and $\operatorname{Exp}(B)$ $2,285)$ on student satisfaction in clinical nursing practice. There is an influence together with students' perceptions about clinical leadership and work environment leadership on student satisfaction in clinical nursing practice. Improving clinical supervisors skills in the form of providing direct assessment when nursing actions, increasing openness and being able to provide confidence to students to be able to carry out nursing action procedures
\end{abstract}

Keywords: Management, Nursing practice, Student satisfaction

\begin{abstract}
Abstrak
Keberhasilan mahasiswa dalam praktek klinik keperawatan sangat ditentukan bagaimana pengelolaan ruang rawat inap yang dipersepsikan mahasiswa sebagai bentuk pengalaman yang dibutuhkan. Tujuan penelitian ini adalah menganalisis pengaruh faktor persepsi mahasiswa dalam pengelolaan ruang rawat inap terhadap kepuasan mahasiswa dalam praktek klinik keperawatan. Jenis penelitian adalah observasional dengan metode analisis kuantitatif. Desain penelitian ini merupakan studi cross sectional. Hasil analisis bivariat menunjukkan adanya hubungan persepsi mahasiswa tentang kepemimpinan pembimbing klinik ( $\mathrm{p}$-value 0,003), supervisi kepala ruangan (p-value 0,042), koordinasi antar pembimbing praktek (p-value 0,032), dan lingkungan kerja praktek (p-value 0,033) dengan kepuasan mahasiswa dalam praktek klinik keperawatan. Hasil analisis multivariat menunjukkan yang paling berpengaruh terhadap kepuasan mahasiswa dalam praktek klinik keperawatan adalah tentang kepemimpinan pembimbing klinik (p-value 0,012 <0,05 dan Exp (B) 3,436) dan lingkungan kerja (p- value 0,010 < 0,05 dan Exp (B) 2,285) terhadap kepuasan mahasiswa dalam praktek klinik keperawatan. Ada pengaruh bersama-sama persepsi mahasiswa tentang kepemimpinan pembimbing klinik dan lingkungan kerja terhadap kepuasan mahasiswa dalam praktek klinik keperawatan. Meningkatkan keterampilan pembimbing klinik berupa memberikan penilaian secara langsung saat tindakan keperawatan, meningkatkan sikap terbuka dan mampu memberikan keyakinan kepada mahasiswa untuk bisa melaksanakan prosedur tindakan keperawatan.
\end{abstract}

Kata kunci: Pengelolaan, Praktek keperawatan, Kepuasan mahasiswa

\section{PENDAHULUAN}

Pada institusi pendidikan keperawatan, mahasiswa diwajibkan mengikuti kegiatan praktek klinik lapangan. Salah satu kegiatan prakteknya ditempatkan diruang rawat inap RSUD Pariaman. Kegiatan praktek mahasiswa keperawatan diruang rawat inap merupakan proses pembelajaran klinik yang sangat dibutuhkan mahasiswa selama praktek. Mahasiswa yang ditempatkan 
diruang rawat inap ini telah menyelesaikan pembelajaran teori diakademik masingmasing.

Keberhasilan praktek klinik keperawatan mahasiswa sangat ditentukan bagaimana pengelolaan ruang rawat inap selama praktek mahasiswa. Kegiatan praktek klinik ini akan dipersepsikan mahasiswa sebagai bentuk pengalaman yang dibutuhkan sesuai harapannya. Semakin besar pengalaman yang didapatkannya sesuai dengan yang diharapkan, maka akan menimbulkan kepuasan kerja selama praktek. Sebagaimana menurut Oliver (1980) dalam Supranto (2016) bahwa kepuasan adalah tingkat perasaan seseorang setelah membandingkan hasil yang dirasakannya dengan harapannya. (Supranto, 2016) Menurut Abraham Maslow bahwa kepuasan seseorang sangat ditentukan oleh pemenuhan kebutuhan berdasarkan tingkatan / hirarki meliputi: pemenuhan kebutuhan fisiologis, keamanan, sosial, pengakuan dan aktualisasi-(Sahervian et al., 2019)

\section{Berdasarkan latar belakang} diatas, maka mahasiswa praktek klinik keperawatan diruang rawat inap berada pada suatu proses pembelajaran pengalaman klinik dimana selalu berinteraksi dan atau sangat ditentukan oleh pengelolaan organisasi ruang rawat inap melalui kepemimpinan pembimbing klinik menggerakkan dirinya terlibat dalam kegiatan praktek klinik keperawatan di ruangan, fungsi supervisi klinik kepala ruangan selama kegiatan praktek, koordinasi antara pembimbing klinik dan pembimbing akademik melibatkan mahasiswa dalam proses bimbingan serta kondisi lingkungan kerja praktek.

Dimana Tujuan penelitian ini adalah menganalisis pengaruh faktor persepsi mahasiswa dalam pengelolaan ruang rawat inap terhadap kepuasan mahasiswa dalam praktek klinik keperawatan.

\section{METODE}

Data Penelitian ini dilakukan dengan pendekatan crosssectional atau studi belah lintang dengan subyek penelitian untuk memberikan gambaran secara lebih jelas tentang masalah pada subyek. Penelitian ini menggunakan metode analisis kuantitatif meliputi deskriptif analitik yaitu untuk menjelaskan atau mengetahui hubungan antara variable bebas dengan variabel terikat dan pengaruhnya. Dimana populasinya adalah 134 mahasiswa berasal dari Akper UNP, 48 orang STIKes Nan Tongga, 38 orang dari STIKes Piala Sakti Pariaman.

Pengumpulan data pada pendelitian ini menggunakan kuesioner dengan sampelmnya dalah mahasiswa keperawatan yang berdinas di RSUD Pariaman secara acak diman terlebih dahulu menguji validitas dan reabilitas kuesioner pada ruangan dan sampel yang berbeda deangan menggunakan infoncent dan memenuhi etika penelitian.

\section{HASIL}

Hasil pada penelitian ini dapat dilihat pada penjelasan berikut:

Tabel 1.

Distribusi Frekuensi Karakteristik

Mahasiswa yang melaksanakan praktek klinik keperawatan di RSUD Pariaman

\begin{tabular}{|c|c|c|c|}
\hline No & Karakteristik & $\mathrm{f}$ & $\%$ \\
\hline 1. & $\begin{array}{ll}\text { Jenis kelamin } \\
-\quad & \text { Perempuan } \\
- & \text { Laki-laki }\end{array}$ & $\begin{array}{l}22 \\
78\end{array}$ & $\begin{array}{l}22,0 \\
78,0\end{array}$ \\
\hline 2. & \begin{tabular}{ll}
\multicolumn{2}{l}{ Pekerjaan orang tua } \\
$-\quad$ PNS/ABRI \\
$-\quad$ Petani \\
$-\quad$ Buruh
\end{tabular} & $\begin{array}{l}31 \\
12 \\
57\end{array}$ & $\begin{array}{l}31,0 \\
12,0 \\
57,0\end{array}$ \\
\hline 3. & $\begin{array}{l}\text { Panghasilan orang tua } \\
-\quad<1 \text { juta } \\
-\quad 1 \text { Juta s/d } 2 \text { Juta } \\
-\quad>2 \text { Juta }\end{array}$ & $\begin{array}{l}20 \\
55 \\
25\end{array}$ & $\begin{array}{l}20,0 \\
55,0 \\
25,0\end{array}$ \\
\hline 4. & \begin{tabular}{ll}
\multicolumn{2}{l}{ Tempat Tinggal } \\
- & Rumah sendiri \\
- & Asrama \\
- & Kontrak/Sewa \\
\end{tabular} & $\begin{array}{l}28 \\
22 \\
50\end{array}$ & $\begin{array}{l}28,0 \\
22,0 \\
50,0\end{array}$ \\
\hline 5. & $\begin{array}{ll}\text { Jarak Rumah } \\
-\quad<7 \mathrm{~km} \\
-\quad 7 \mathrm{~s} / \mathrm{d} 17 \mathrm{~km} \\
-\quad<17 \mathrm{~km} \\
\end{array}$ & $\begin{array}{l}55 \\
15 \\
30 \\
\end{array}$ & $\begin{array}{l}55,0 \\
15,0 \\
30,0 \\
\end{array}$ \\
\hline
\end{tabular}




\begin{tabular}{clll}
\hline 6. & Transportasi & & \\
& $-\quad$ Jalan kaki & 12 & 12,0 \\
& $-\quad$ Motor & 53 & 53,0 \\
& $-\quad$ Mobil & 35 & 35,0 \\
\hline 7. & Lama Perjalanan & & \\
& $-\quad<15$ Menit & 38 & 38,0 \\
& $-\quad 15-30$ Menit & 24 & 24,0 \\
& $-\quad<30$ Menit & 38 & 38,0 \\
\hline
\end{tabular}

Berdasarkan tabel 1 dapat dilihat bahwa $78 \%$ responden berjenis kelamin laki- laki dan $22 \%$ berjenis kelamin perempuan, pekerjaan orang tua responden dalam penelitian ini PNS/ABRI 31\%, Petani / Buruh $12 \%$, dan Swasta $57 \%$, penghasilan orang tua responden dalam penelitian ini $<1$ juta $20 \%, 1$ juta s/d 2 juta $55 \%,>2$ juta $25 \%$, tempat tinggal responden do rumah sendiri $28 \%$, asrama pendidikan $22 \%$, dan rumah kontrak/ sewa $50 \%$. Jarak tempat tinggal responden dengan rumah sakit kurang dari $7 \mathrm{~km} 55$ $\%, 7 \mathrm{~km}$ sampai $17 \mathrm{~km} 15 \%$, dan jarak rumah sakit lebih dari $17 \mathrm{~km} 30 \%$, transportasi yang di gunakan dari rumah ke rumah sakit adalah jalan kaki $12 \%$, menggunkana motor $53 \%$, dan dengan mobil $35 \%$. Lama perjalanan responden ke rumah sakit kurang dari 15 menit 38\%, 15 menit sampai 30 menit $24 \%$,dan lama perjalanan ke rumah sakit lebih dari 30 menit $38 \%$.

Tabel 2.

Distribusi Frekuensi Persepsi

Mahasiswa tentang Kepemimpinan, Supervisi, koordinasi Pembimbing, dan Lingkungan kerja di Ruang Rawat Inap RSUD Pariaman

\begin{tabular}{clcc}
\hline No & Karakteristik & F & $\%$ \\
\hline 1. & Kepemimpinan & & \\
& $-\quad$ Baik & 55 & 55,0 \\
& $-\quad$ Tidak baik & 45 & 45,0 \\
\hline 2. & Supervisi & & \\
& $-\quad$ Baik & 44 & 44,0 \\
& $-\quad$ Tidak Baik & 56 & 56,0 \\
\hline 3. & Koordinasi & & \\
& $-\quad$ Baik & 54 & 54,0 \\
$\quad$ - Tidak baik & 46 & 46,0 \\
\hline 4. & Lingkungan Kerja & & \\
& $-\quad$ Baik & 37 & 37,0 \\
& $-\quad$ Tidak B9aik & 63 & 63,0 \\
\hline
\end{tabular}

Berdasarkan tabel 2 dapat dilihat bahwa 55 orang $(55 \%)$ persepsi mahasiswa tentang kepemimpinan pembimbing klinik baik, 56 orang $(56 \%)$ persepsi mahasiswa tentang supervisi kepala ruangan di ruang rawat inap tidak baik, 54 orang ( $54 \%$ ) persepsi mahasiswa tentang koordinasi antar pembimbing klinik di ruang rawat inap baik, dan 63 orang (63\%) persepsi mahasiswa tentang lingkungan kerja praktek klinik di ruang rawat inap tidak baik.

Tabel 3

Distribusi Frekuensi Kepuasan

Mahasiswa dalam Praktek Klinik Keperawatan di Ruang Rawat Inap RSUD Pariaman

Berdasarkan tabel 3 dapat dilihat

\begin{tabular}{|c|c|c|}
\hline $\begin{array}{c}\text { Kepuasan } \\
\text { Mahasiswa }\end{array}$ & $\dot{\mathbf{f}}$ & $\%$ \\
\hline Baik & 65 & 65 \\
\hline Tidak Baik & 35 & 35 \\
\hline Jumlah & 100 & 100 \\
\hline \multicolumn{3}{|c|}{$\begin{array}{l}\text { bahwa } 65 \text { orang }(65 \%) \text { kepuasan } \\
\text { mahasiswa dalam praktek klinik di ruang } \\
\text { rawat inap baik dan } 35 \text { orang ( } 35 \%) \\
\text { mahasiswa mempersepsikan kepuasan } \\
\text { mahasiswa dalam praktek klinik di ruang } \\
\text { rawat inap tidak baik. }\end{array}$} \\
\hline
\end{tabular}


Tabel 4

Hubungan Persepsi Mahasiswa tentang Kepemimpinan Pembimbing Klinik, Supervisi, Koordinasi, dan Lingkungan

Kerja terhadap Kepuasan Mahasiswa dalam

Praktek Klinik Keperawatan Di Rawat Inap RSUD PariamanTahun 2019(n=100)

\begin{tabular}{|c|c|c|c|c|c|c|}
\hline \multirow{3}{*}{ Variabel } & \multicolumn{4}{|c|}{ Kepuasan Mahasiswa } & \multirow[b]{2}{*}{ Total } & \multirow{2}{*}{$\begin{array}{c}\mathrm{P} \\
\text { Value }\end{array}$} \\
\hline & Tidak & Puas & \multicolumn{2}{|c|}{ Puas } & & \\
\hline & $\mathrm{n}$ & $\%$ & $\mathrm{n}$ & $\%$ & $\mathrm{n}$ & \\
\hline Kepemimpinan & & & & & & \\
\hline Tidak Baik & 29 & 64,5 & 16 & 35,5 & 45 & 0,003 \\
\hline Baik & 12 & 21,8 & 43 & 78,2 & 55 & \\
\hline Supervisi & & & & & & \\
\hline Tidak Baik & 18 & 41,0 & 26 & 59,5 & 44 & 0,042 \\
\hline Baik & 15 & 26 & 41 & 73,2 & 56 & \\
\hline Koordinasi & & & & & & \\
\hline Tidak Baik & 14 & 25,9 & 40 & 59,5 & 54 & 0,32 \\
\hline Baik & 21 & 45,6 & 25 & 73,2 & 46 & \\
\hline
\end{tabular}

\begin{tabular}{lcccccc}
\hline $\begin{array}{l}\text { Lingkungan } \\
\text { Kerja }\end{array}$ & & & & & & \\
Tidak Baik & 24 & 64,8 & 19 & 35,1 & 37 & 0,033 \\
$\quad$ Baik & 17 & 26,5 & 46 & 71,8 & 63 &
\end{tabular}

\section{PEMBAHASAN}

Kepemimpinan dalam keperawatan merupakan penggunaan penampilan seorang pemimpin dalam mempengaruhi perawat-perawat lain dibawah pengawasannya untuk pembagian tugas dan tanggungjawabnya dalam memberikan pelayanan dan asuhan keperawatan sehingga tujuan keperawatan tercapai.(Rismayadi \& Maemunah, 2016) Terkait dengan hal tersebut berdasarkan sebaran jawaban mahasiswa tentang persepsinya terhadap kepemimpinan pembimbing klinik masih ditemukan bahwa $16 \%$ pembimbing klinik tidak memberi kesempatan kepada mahasiswa dalam pengambilan keputusan tindakan keperawatan, $28 \%$ mahasiswa kurang setuju pembimbing klinik meyakinkan dirinya untuk bisa melakukan prosedur tindakan keperawatan.
Sesuai menurut Butterworth (2001), bahwa kepala ruangan sebagai supervisor harus memiliki kemampuan memberikan pengarahan yang jelas, saran yang dibutuhkan mahasiswa, motivasi semangat kerja mahasiswa dan memberikan bimbingan dan latihan (Resmana et al., 2014) Sedangkan menurut Fayol (2003), bahwa supervisi adalah salah satu upaya pengarahan dengan pemberian petunjuk dan saran, setelah menemukan alasan dan keluhan pelaksana dalam mengatasi permasalahan yang dihadapi. Dilanjutkan menurut Burre dan Rolfe (2001), bahwa supervisi klinis adalah sebagai proses formal di mana seorang siswa terlibat dalam pengalamanannya dengan orang yang lebih berpengalaman untuk belajar dan meningkatkan keahlian terapi melalui penggunaan bahan permasalahan. (Layuk et al., 2017)

Berdasarkan data sebaran jawaban mahasiswa tentang persepsinya terhadap koordinasi antar pembimbing praktek, maka (54 \%) mahasiswa menyatakan adanya duplikasi tugas praktek keperawatan yang diberikan kepada mahasiswa oleh pembimbing klinik dan akademik dan $33 \%$ mahasiswa menyatakan masih seringnya tidak ada bimbingan selama praktek oleh pembimbing klinik karena tidak ada komunikasi.

Menurut Siagian (2018), bahwa koordinasi adalah pengaturan tata hubungan dari usaha bersama untuk memperoleh kesatuan tindakan dalam pencapaian tujuan bersama. Koordinasi merupakan suatu proses yang mengatur agar pembagian kerja dari berbagai orang atau kelompok dapat tersusun menjadi suatu kebulatan yang terintegrasi dengan cara yang seefisien mungkin. (Siagian, 2018).

Sebagaimana sebaran jawaban mahasiswa tentang persepsinya terhadap lingkungan kerja praktek masih ditemukan $35 \%$ mahasiswa menyatakan ruangan tempat praktek yang kurang sejuk, menyatakan kurang bersih $22 \%$, 
menyatakan kurang tenang $19 \%$, menyatakan kurang terang $18 \%$ dan $16 \%$ mahasiswa menyatakan kurang setuju ketersedianya alat-bahan keperawatan saat tindakan keperawatan. Selanjutnya menurut Maslow, bahwa kepuasan dapat berasal dari terpenuhinya pemenuhan kebutuhan sosial dan keamanan sebagai kebutuhan berjenjang meliputi : perhatian, merasa bersatu dan kontak dengan orang lain, merasa aman serta bebas dari ketakutan dan ancaman.(Yanti \& Warsito, 2013)

Berdasarkan sebaran jawaban mahasiswa juga ditemukan bahwa $28 \%$ mahasiswa menyatakan tidak ada ruangan khusus untuk diskusi selama praktek, 27 tersedianya bahan bacaan penunjang praktek keperawatan berupa buku-buku keperawatan dan $20 \%$ mahasiswa menyatakan kurang setuju bekerja sesuai SOP.(Winasih et al., 2015).

\section{KESIMPULAN}

Persepsi mahasiswa tentang kepemimpinan pembimbing klinik dan lingkungan kerja memiliki pengaruh paling besar terhadap kepuasan mahasiswa dalam praktek klinik keperawatan di RSUD Pariaman. Mahasiswa yang mempunyai persepsi tentang kepemimpinan pembimbing klinik tidak baik mempunyai kecenderungan menjadi tidak puas kepemimpinan pembimbing klinik (p-value 0,012 <0,05 dan $\operatorname{Exp}(\mathrm{B}) 3$,436) dan lingkungan kerja tidak puas (p- value 0,010 $<0,05$ dan Exp (B) 2,285) terhadap kepuasan mahasiswa dalam praktek klinik keperawatan.

\section{UCAPAN TERIMA KASIH}

Terimakasih saya ucapkan kepada semua pihak yang terlibat dalam penelitian ini, terkhususnya kepada Kemenristek Dikti, LLDikti, Yayasan STIKes Piala Sakti, Direktur RSUD Pariaman.

\section{DAFTAR PUSTAKA}

Dep Kes RI. (2010) Pedoman Pelayanan RS Kelas B,Cetakan pertama, Direktorat Jenderal Pelayanan Medik,2010.

Layuk, Y. T., Harjanto, T., \& Hapsari, E. D. (2017). HUBUNGAN PERSEPSI LINGKUNGAN PEMBELAJARAN KLINIK DENGAN PERILAKU CARING PADA MAHASISWA PROFESI NERS. Jurnal Persatuan Perawat Nasional Indonesia (JPPNI). https://doi.org/10.32419/jppni.v1i2.24

Resmana, B., Saichudin, -, \& Januarto, O. B. (2014). Survei Tingkat Kesegaran Jasmani Peserta Ekstrakurikuler Bola Basket Sma Negeri 2 Lumajang. Jurnal Pendidikan Jasmani.

Rismayadi, B., \& Maemunah, M. (2016). Pengaruh Motivasi Kerja, Kepemimpinan dan Budaya Organisasi Terhadap Kepuasan Kerja Karyawan serta Dampaknya pada Kinerja Perusahaan (Studi kasus pada PT. Concord Indonesia). Jurnal Manajemen \& Bisnis Kreatif.

https://doi.org/10.36805/manajemen.v2i1 .181

Sahervian, R. R., Adi, W. B., \& Sunarto. (2019). Pengaruh Budaya Organisasi, Kepemimpinan Dan Disiplin Kerja Terhadap Kinerja Organisasi Laboratorium Pendidikan Ekonomi Mini Market Tania Tahun 2018. Jurnal Pendidikan Bisnis Dan Ekonomi.

Siagian, M. (2018). Peranan Disiplin Kerja Dan Kompensasi Dalam Mendeterminasi Kinerja Karyawan Dengan Motivasi Kerja Sebagai Variabel Intervening Pada Pt Cahaya Pulau Pura Di Kota Batam. JIM UPB (Jurnal Ilmiah Manajemen Universitas Putera Batam). https://doi.org/10.33884/jimupb.v6i2.675 
NERS: Jurnal Keperawatan, Volume 16, No. 2, Oktober 2020, (Hal. 103-108)

Supranto. (2016). Mengukur Tingkat Kepuasan Pelanggan atau Konsumen. Insan.

Winasih, R., Nursalam, \& Dian, N. (2015). Budaya organisasi dan Quality of Nursing Work Life Terhadap Kinerja dan Kepuasan Kerja Perawat Di RSUD Dr. Soetomo Surabaya. Ners.

Yanti, R., \& Warsito, B. (2013). Hubungan Karakteristik Perawat, Motivasi, Dan Supervisi Dengan Kualitas Dokumentasi Proses Asuhan Keperawatan. Jurnal Manajemen Keperawatan. 